\title{
THE EFFECTS OF DIFFERENT TYPES OF WOODSTAND DISTURBANCE ON THE PERSISTENCE OF SOIL SEED BANKS
}

\author{
ANNA J. KWIATKOWSKA-FALIŃSKA ${ }^{1}$, DOROTA PANUFNIK-MĘDRZYCKA ${ }^{2}$, \\ MACIEJ WÓDKIEWICZ ${ }^{2}$, IZABELA SONDEJ ${ }^{3}$, BOGDAN JAROSZEWICZ ${ }^{1}$ \\ ${ }^{1}$ Białowieża Geobotanical Station, Institute of Botany, \\ Faculty of Biology, University of Warsaw \\ Sportowa 19, 17-230 Białowieża, Poland \\ e-mail: ajkf@biol.uw.edu.pl \\ 2 Department of Plant Ecology and Nature Protection, \\ Institute of Botany, Faculty of Biology, University of Warsaw \\ Al. Ujazdowskie 4, 00-478 Warszawa, Poland \\ ${ }^{3}$ Department of Anatomy and Vertebrate Zoology, \\ University of Szczecin \\ Wąska 13, 71-415 Szczecin, Poland
}

(Received: May 12, 2010. Accepted: November 26, 2010)

\begin{abstract}
The research was conducted on four patches of thermophilous oak wood in Białowieża Primeval Forest: A with a woodstand: oak + approx. 30-year-old hornbeam + hornbeam brushwood; B - with a hornbeam stand formed by natural seed fall after logging (ca. 1920) oaks; C - after logging oaks and replanted (ca. 1965) with pine and oak; D - with a natural low-density oak stand. Species composition and seed bank density were estimated using the seedling emergence method. Seedling emergence was observed over two vegetation seasons. Research demonstrated that: 1) the species abundance of the seed banks depends on canopy cover (A, B approx. 50 species; C, D approx. 70 species); 2) the floristical similarity (Sørensen's index) of the seed bank and ground vegetation is higher in the undisturbed patch $\mathrm{D}(0.50)$ than in disturbed patches $(0.30-0.35) ; 3)$ species diversity in plots A, B, C, D ( $\left.\mathrm{H}^{\prime}=12.5 ; 13.4 ; 15.5 ; 16.9\right)$ and seed bank density per $\mathrm{m}^{2}(432.5 ; 958.0 ; 1486.5 ; 2268.0)$ are negatively correlated with the degree of patch shading; 4) the average weight of diaspores in the seed banks of shady plots is lower (A, B approx. $0.003 \mathrm{~g}$ ) than that of sunny plots (C, D approx. $0.08 \mathrm{~g}$ ); 5) the share of long-lived diaspores increases in patches after logging.
\end{abstract}

KEY WORDS: density; disturbance; frequency; longevity index; persistence; soil seed bank.

\section{INTRODUCTION}

The Potentillo albae-Quercetum community is the only thermophilous forest in Białowieża Primeval Forest. The characteristic composition of species in this community covers a wide ecological spectrum of species with contrasting demands for light, moisture and trophic conditions (Kwiatkowska 1993). In the Polish part of Białowieża Primeval Forest Potentillo albae-Quercetum communities have been found only on the plateau and the southern slopes of moraine and kame hills, and they are surrounded by shady hornbeam forest Tilio-Carpinetum (Kwiatkowska 1986). The area covered by thermophilous oak forest continues to decrease for various reasons. Many thermophilous oak wood habitats were destroyed between World War I and II due to the construction of a railway line and gravel and sand pits. In the same period a number of thermophilous oak wood patches were destroyed by the logging of woodstands which were precious for economic reasons (Faliński 1986). Over the past forty years the preserved patches have rapidly declined. This process has resulted directly from the invasion of hornbeam into habitats of thermophilous oak wood (Kwiatkowska and Wyszomirski 1988, 1990; Kwiatkowska et al. 1997). Hornbeam invasion resulted from repetitive changes in the type and level of pressure from herbivores (on trees, shrubs and herbaceous plants) in the 18th, 19th and 20th century (Kwiatkowska 1996; Kwiatkowska-Falińska 2006). Hornbeam specimens growing above the ground vegetation layer increase overshading of the forest floor and trigger the gradual deletion of species, with speed positively correlated with light demands (Kwiatkowska 1994a). Growing hornbeam brushwood causes the gradual transformation of a thermophilous oak forest patch towards the sur- 
rounding Tilio-Carpinetum (Kwiatkowska and SolińskaGórnicka 1993). Currently, in Białowieża Primeval Forest there are no thermophilous oak forests with natural woodstands and diversified ground vegetation formed by numerous heliophilous species (Kwiatkowska 1996). The soil seed bank, defined as a pool of seeds with germinating potential present in the soil, is considered a type of "evolutionary memory" for the plant community, preserving past events (Harper 1977). Even with clear logging the previously deposited seeds are able to survive in the soil. When conditions are suitable for diaspore germination, the seed bank may play a significant role in the restoration of the community (Kwiatkowska and Solińska-Górnicka 1993). However, there is a common opinion in the literature that the species composition in the seed bank of forest communities demonstrates low similarity to ground vegetation (Pickett and McDonnell 1989; Thompson 1992; Dölle and Schmidt 2009; Wódkiewicz and Kwiatkowska-Falińska 2010a, 2010b). In addition, some authors claim that the low-abundance and diversified seed bank of forest communities is dominated by heliophilous species, typical for early succession stages. These species demand a large amount of light, both for germination and further development (Thompson and Grime 1979). However, the results of research conducted in Białowieża Primeval Forest have not confirmed these conclusions. Floristical similarity between the ground vegetation and the seed bank both in undisturbed and disturbed Tilio-Carpinetum communities is high (70\%) (Jankowska-Błaszczuk et al. 1998; PanufnikMędrzycka and Kwiatkowska-Falińska 2001). In TilioCarpinetum communities it attains similarly high values, both in a patch with natural woodstand and that which formed spontaneously 90 years following logging (Jankowska-Błaszczuk and Grubb 1997). In the discussed communities species abundance was also high. The observation of seedling emergence conducted over one vegetation season demonstrated 45 species in the seed bank of Tilio-Carpinetum and 51 species in that of Potentillo albaeQuercetum (Jankowska-Błaszczuk et al. 1998). These groups of species included a high number (approx. 30\%) of ancient forest species. The main disturbance factor in forest communities is the rapid natural or anthropogenic increase in the access of the full light spectrum to ground vegetation.

The seed bank of the Tilio-Carpinetum patch with a secondary woodstand demonstrated a higher share of heliophilous species than the patch with natural woodstand. However, these species do not represent early succession stages, but a strategy of waiting for large-scale disturbances of the tree canopy. For germination they require access to the full light spectrum (Jankowska-Błaszczuk and Grubb 1997; Jankowska-Błaszczuk and Daws 2007). In forests with highly shaded ground vegetation, such as Tilio-Carpinetum, the seed bank is enriched with heliophilous species which grow in gaps in the first year during the process of gradual gap filling. The increased size of the seed bank by species from taxa: Urtica, Hypericum, Juncus provides clear information about past disturbance (Jankowska-Błaszczuk and Grubb 1997). It should be assumed that in Potentillo albae-Quercetum communities, characterised by good access of light to the ground vegetation layer, clearing trees probably less significantly changes the size and diversity of the seed bank than disturbances caused by increased shading of the forest floor by invading hornbeam trees.

The objective of the study was to analyse the effects of logging and hornbeam recruitment in oak forest on floristical similarity of the seed banks and vegetation and on seed banks diversity and density. Logging is expected to increase diversity and density of seed banks, while hornbeam recruitment is expected to have opposite effect. We hypothesise also that both types of disturbances should decrease similarity between seed bank and vegetation.

\section{Study area and characteristics of study sites}

The study was conducted on four $480 \mathrm{~m}^{2}$ permanent plots (objects: A, B, C, D) located in the central part of the Polish fragment of Białowieża Primeval Forest. Plots A, B and $\mathrm{D}$ were located in a landscape reserve and plot $\mathrm{C}$ was established in the area of production forests.

Object A - research site located in forest district 442B. It covered a fragment of a thermophilous oak wood patch strongly transformed by approx. 30-year-old hornbeam, physiognomically similar to floristically low-diversified Tilio-Carpinetum with a high share of juvenile hornbeams in the shrub layer (50\%). Carpinus betulus was a dominant woodstand species, and was accompanied by Quercus robur and Picea abies. Trees-cover in this patch was 80$100 \%$, and the ground vegetation cover was very low, not exceeding $20 \%$. The mean number of species per $100 \mathrm{~m}^{2}$ was 25. The majority of species were characteristic for deciduous forests.

Object B - research site located in forest district 386A. It covered a fragment of thermophilous oak wood patch at an advanced stage of decline. The patch was physiognomically similar to Tilio-Carpinetum typicum. In the 1920 s a natural oak forest had been logged and the current tree stand formed spontaneously from natural seed fall. The shrub layer was poorly developed $(10 \%)$. The woodstand was dominated by hornbeam, with an admixture of birch, spruce and oak. The canopy cower was high (70-80\%), while the ground vegetation cover demonstrated relatively low diversity (on average 39 species per $100 \mathrm{~m}^{2}$ ). The vegetation cover was $40-50 \%$.

Object C - research site located in forest district 543C. It covered a fragment of thermophilous oak wood patch on a slope and plateau of a kame hill. In the 1960s a natural oak forest had been logged and the soil ploughed prior to planting of Pinus sylvestris and Quercus robur. During the study a low canopy cover woodstand (30-50\%) was dominated by restoring pine, with an admixture of oak, hornbeam and spruce. The vegetation was relatively rich (on average 77 species per $100 \mathrm{~m}^{2}$ ) and luxuriant. It covered $60-80 \%$ of the plot and was characterised by a high proportion of heliophilous species.

Object D - research site located in forest district 442B. It covered a fragment of a previously extensive patch of thermophilous oak wood (the same as in plot A). In this part hornbeam invasion has only just begun, and its juvenile specimens were not higher than the ground vegetation. The tree layer was formed by old oaks. Canopy density was below $45 \%$. Luxuriant, rich ground vegetation has survived here, (on average 82 species per $100 \mathrm{~m}^{2}$ ) covering $80 \%$ of the plot. The species composition and structure of the ground vegetation was typical for Potentillo albae-Quercetum. 

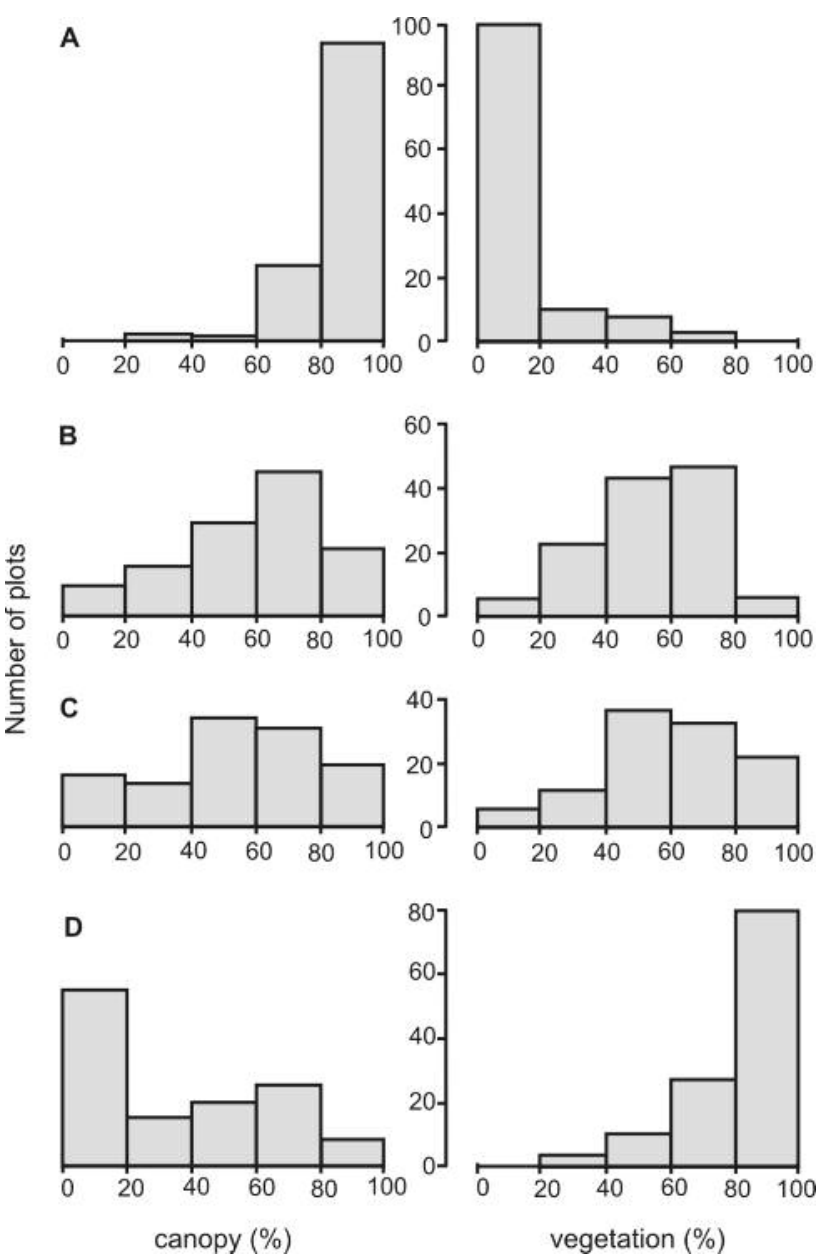

Fig. 1. Canopy and vegetation cover (\%) in research objects (A-D).

\section{Characteristics of light conditions in the study area}

Research plots were characterised by significant differences in the access of light to the forest floor, both for a modal value of canopy density and in the proportion of strongly shaded plots (Fig. 1). In plot A almost all subplots were strongly shaded (canopy density $>80 \%$ ) by hornbeam, which in this plot formed the woodstand $\mathrm{A}_{2}$ and is encountered in brushwood. In plot B an old hornbeam stand, in which maximum of the process of natural selection of trees is over, strongly shades about $50 \%$ of the area. Small gaps have formed between tree crowns. In plot $\mathrm{C}$ fairly strong $(>50 \%)$ shading concerns a half of the subplots, but, apart from numerous gaps in the canopy, the light penetrates to the forest floor via open-structure pine crowns. The highest number and area of gaps was found in plot D, where almost a half of the plots are only $20 \%$ shaded. The rate of cover for ground vegetation depends on access to light. On the most shaded subplots and plots the rate is very low $(<20 \%)$, and it is very high in places with good access to light (Fig. 1).

\section{Field sampling}

In each of the four $480 \mathrm{~m}^{2}$ plots $(12 \times 40 \mathrm{~m}) 120$ subplots were established $(2 \times 2 \mathrm{~m})$. In summer 1997 species of vascular plants were surveyed on each plot, and the rate of cover for ground vegetation as well as for canopy were calculated.

Samples were collected for the analysis of the soil seed bank in early spring 1997 from a transect $(2 \times 40 \mathrm{~m})$ located within the research plots. Litter covering mineral soil was removed prior to sample collection. Soil cores from each $2 \times 2 \mathrm{~m}$ plot were collected with an open-ended soil probe $\left(100 \mathrm{~cm}^{3}\right)$ to obtain a $6000 \mathrm{~cm}^{3}$ total sample volume for each subplot. Afterwards, each soil sample was separately sorted to remove underground plant parts and gravel. A $4000 \mathrm{~cm}^{3}$ sample was collected from the remaining soil and placed in $0.1 \mathrm{~m}^{2} \times 7 \mathrm{~cm}$ containers.

\section{Greenhouse procedure}

The species composition and seed bank density were determined using the seedling emergence method (Ter Heerdt et al. 1996; Leck et al. 1989). The containers were kept in an unheated greenhouse, where the temperature in winter was below $0^{\circ} \mathrm{C}$. Seedling emergence was observed over two vegetation seasons (until November 1998). When necessary, samples were watered with distilled water to maintain constant soil humidity. After identification and counting, seedlings were removed, and then the soil in the containers was stirred thoroughly to enable the germination of diaspores from deeper layers.

\section{Data analysis}

Frequency of ground vegetation species for objects was calculated based on their frequency of occurrence on 120 subplots. Frequency of species in the seed bank was calculated based on the occurrence of species in 20 soil samples.

Species diversity in ground vegetation and seed bank for individual plots was calculated based on the ShannonWeiner diversity coefficient: $H^{\prime}=-\Sigma p_{i} \ln p_{i}$; where $p_{i}$ was calculated based on the frequency of species in the ground vegetation and seed bank.

Floristical similarity between the species in the seed bank and ground vegetation was calculated using the Sørensen similarity index (Sørensen 1948; Hopfensperger 2007).

For the seed bank of each objects the following characteristics were calculated: number of species in the total samples, average number of species $\overline{(x)}$, standard deviation (SD) per $0.1 \mathrm{~m}^{2}$ and $\bar{x}$ number of seedlings \pm SD per $0.1 \mathrm{~m}^{2}$.

The persistence of soil seed banks was estimated based on the longevity index (LI), which for persistent seed banks has values from 0 to 1 . Literature data (Thompson et al. 1997) for the calculation of LI were found for 88 species. Mean values of LI and SD were calculated based on them for each objects.

The seed longevity index (LI) was calculated for each species found in the seed bank using a method by Thompson et al. (1997) and Bekker et al. (1998, 1999).

The significance of differences between the average values was analysed with the $t$-Student test (Sokal and Rolf 1981). The comparison of mean LI and mean particular of objects (A, B, C, D) was also conducted based on the standardized variable $\mathrm{u}=\bar{x}_{\mathrm{i}}-\bar{x} / \mathrm{SD}$, where $\bar{x}_{\mathrm{i}}-$ mean for species in the seed bank of the individual plot, $\bar{x}$ - mean for all species encountered in the seed banks of four objects.

\section{RESULTS}

\section{Similarity and species diversity} of the ground vegetation and seed bank

The studied objects demonstrated low similarity of species composition in the ground vegetation (Table 1). 
TABLE 1. Value of Sørensen's index of similarity between particular objects (A-D) regarding the seed banks and ground vegetation.

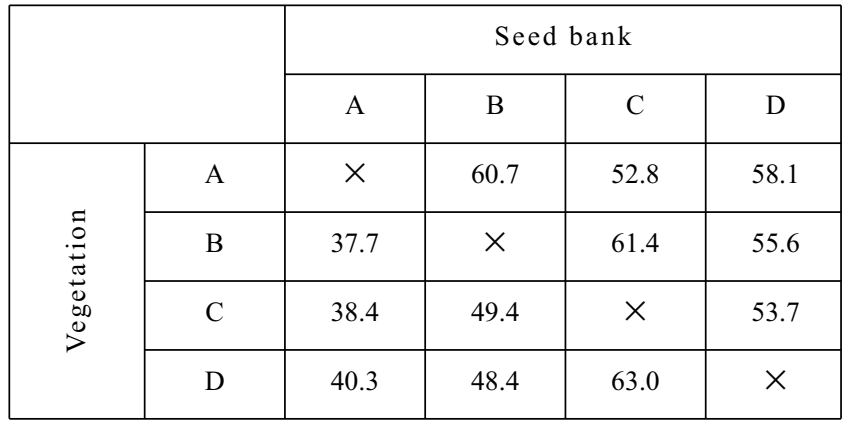

Values of the floristical similarity index $\mathrm{S}$ calculated for all paired plots range within approx. 40-60\%. The closest similarity $(S=63.0 \%)$ was demonstrated for plots $C$ and $D$. Both plots were characterised by low-density woodstand,
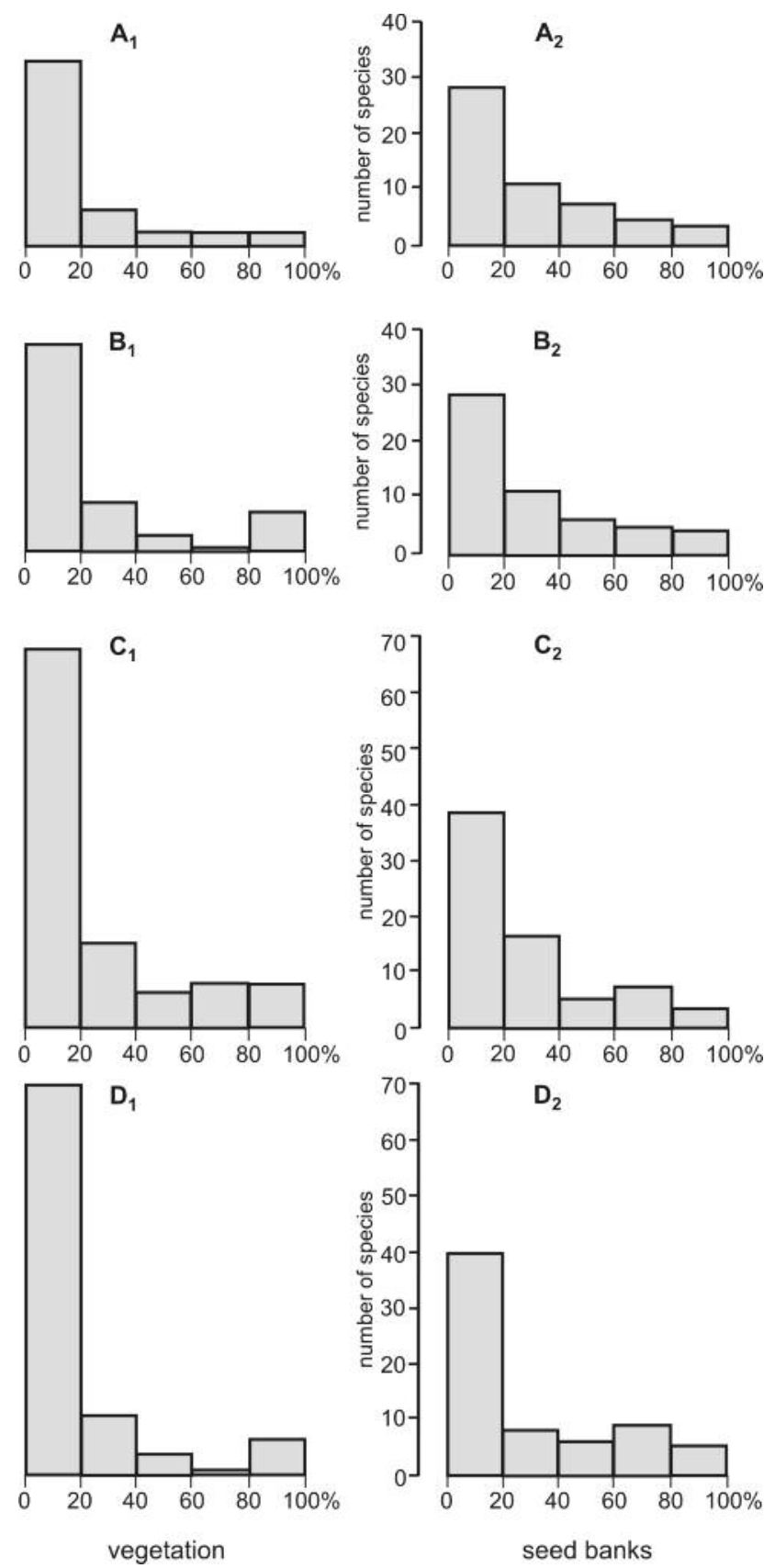

Fig. 2. Frequency of species in the vegetation $\left(A_{1}-D_{1}\right)$ and in the seed banks $\left(A_{2}-D_{2}\right)$ of research objects. which allowed for the penetration of large amounts of light to the ground vegetation (Fig. 1).

On the study plots both species diversity and the above ground vegetation cover were negatively correlated with canopy density. In plots $\mathrm{C}$ and $\mathrm{D}$ the number of species was least two times higher than in the strongly shaded plots, A and B. In total, 159 taxa were encountered on four plots, including 47 ancient forest species. In all plots lowfrequency species $(<20 \%)$ had the highest share. High-frequency species in a plot (80-100\%) had a very low share (Fig. 2).

The seed banks of individual plots demonstrated higher floristical similarity to each other than the ground vegetation. $\mathrm{S}$ values range in a twice lower spectrum (50-60\%). The closest similarity between seed banks was demonstrated for plots $B$ and $C(S=61.4 \%)$, which have been formed over several dozen years following logging (Table 1).

The analysis of all samples of soil seed bank demonstrated the presence of 125 taxa, of which 95 were also present in the ground vegetation. Species abundance of the seed banks in individual plots ranged within a more narrow spectrum (min. 50, max. 70 species) than in the ground vegetation (min. 53, $\max 116$ ). In both cases ancient forest species were present in the plots. Low-frequency species $(<20 \%)$ dominated in the seed bank of all plots $(>50 \%)$. The structure of species from different frequency classes in the seed bank was slightly more balanced than in the ground vegetation (Fig. 2). In both cases J-shaped histograms were obtained.

The diversity coefficients (number of species in a plot and value of H' coefficient) calculated for the ground cover and seed bank classified plots A, B, C, D in a similar manner from the least diversified A to the most diversified D (Table 2 ). Values of the H' coefficient calculated for ground vegetation classified plots into two groups: $\mathrm{A}$ and $\mathrm{B}\left(\mathrm{H}^{\prime}=7.2\right.$ and $\left.H^{\prime}=8.4\right)$ and $C$ and $D\left(H^{\prime}=19.6\right.$ and $\left.H^{\prime}=18.7\right)$. Values $H^{\prime}$ calculated for the seed banks of individual plots were less diversified than for the ground vegetation (Table 2).

Floristical similarity between seed banks and vegetation in plots $\mathrm{A}, \mathrm{B}$, and $\mathrm{C}$ was low ( $\mathrm{S}$ index approx. 30\%). The seed bank of plot $\mathrm{D}$, with the least disturbed woodstand structure, demonstrated the closest floristical similarity to the ground vegetation ( $\mathrm{S}=49.1 \%$, Table 2$)$.

\section{Persistence of seed bank and weight of diaspores}

Analysis of persistence was conducted for a group of species for which information for the calculation of LI was available and the weight of seeds was known (Table 3). For that reason the analysis was performed for a lower number of species: $(A=46 / 55 ; B=45 / 57 ; C=52 / 70 ; D=58 / 69$; a denominator indicated the number of species found in the seed bank of a particular plot).

We assumed that the seed banks formed by long-lived species would have a higher mean LI than the banks dominated by short-lived diaspores. Therefore, our assumption was that in plots $\mathrm{A}$ and $\mathrm{B}$, invaded by hornbeam for over 30 years, the seed banks would contain the diaspores of species forming persistent seed banks. Thus, the mean LI for plots A and B should be higher than the mean LI calculated for $C$ and $D$. No statistical proof $\left(t_{i}>t_{0}\right)$ for this hypothesis was obtained owing to the high variability of LI. However, mean values expressed as standardized variable $u$ categorized plots into two groups: never logged (A 
TABLE 2. Characteristics of the seed banks of research plots.

\begin{tabular}{|c|c|c|c|c|}
\hline Seed bank & A & $\mathrm{B}$ & $\mathrm{C}$ & $\mathrm{D}$ \\
\hline Number of species & 55 & 57 & 70 & 69 \\
\hline$\overline{\mathrm{x}}$ number of species $0.1 \mathrm{~m}^{2}$ & $12.4 \pm 2.7$ & $13.0 \pm 3.8$ & $21.5 \pm 6.6$ & $20.7 \pm 4.8$ \\
\hline$\overline{\mathrm{x}}$ number of seedlings $0.1 \mathrm{~m}^{2}$ & $43.3 \pm 45.8$ & $95.8 \pm 37.0$ & $74.3 \pm 35.3$ & $73.4 \pm 35.6$ \\
\hline $\begin{array}{l}\overline{\mathrm{X}} \text { number of seedlings } 0.1 \mathrm{~m}^{2} \\
\mathrm{~L}=0,1,2\end{array}$ & $2.6 \pm 1.0$ & $0.9 \pm 0.7$ & $1.1 \pm 0.9$ & $2.1 \pm 1.2$ \\
\hline $\begin{array}{l}\bar{x} \text { number of seedlings } 0.1 \mathrm{~m}^{2} \\
\mathrm{~L}=3,4,5\end{array}$ & $3.0 \pm 1.4$ & $3.1 \pm 1.8$ & $4.3 \pm 2.5$ & $5.8 \pm 2.0$ \\
\hline $\begin{array}{l}\overline{\mathrm{x}} \text { number of seedlings } 0.1 \mathrm{~m}^{2} \\
\mathrm{~L}=6,7,8\end{array}$ & $5.7 \pm 2.0$ & $7.4 \pm 2.4$ & $14.5 \pm 4.0$ & $12.1 \pm 3.2$ \\
\hline Shannon's index H' & 12.5 & 13.4 & 15.5 & 16.9 \\
\hline $\begin{array}{l}\text { Sørenson's index } \\
\text { (seed bank/vegetation) }\end{array}$ & 34.8 & 31.3 & 30.3 & 49.1 \\
\hline Longevity index & $\begin{array}{l}0.433 \\
0.344\end{array}$ & $\begin{array}{l}0.464 \\
0.348\end{array}$ & $\begin{array}{l}0.471 \\
0.330\end{array}$ & $\begin{array}{l}0.396 \\
0.358\end{array}$ \\
\hline Weight of seed & $\begin{array}{l}0.003 \\
0.008\end{array}$ & $\begin{array}{l}0.003 \\
0.007\end{array}$ & $\begin{array}{l}0.084 \\
0.562\end{array}$ & $\begin{array}{l}0.079 \\
0.539\end{array}$ \\
\hline
\end{tabular}

and D) and logged B and C (Fig. 3). The distribution of LI for all plots is bimodal (Fig. 4) and highly variable (SD close to $x$, Table 2 ). The peaks probably correspond with the pool of short-lived $(\mathrm{LI}=0-0.4)$ and long-lived seeds $(\mathrm{LI}>0.6)$.

When assuming the correlation between the weight of seeds and longevity we expected the mean weight of seeds from the banks of plots A and B to be lower than that of C and $D$. Such a tendency was revealed when mean values for plots were expressed in units of standardized variable $u$.

a

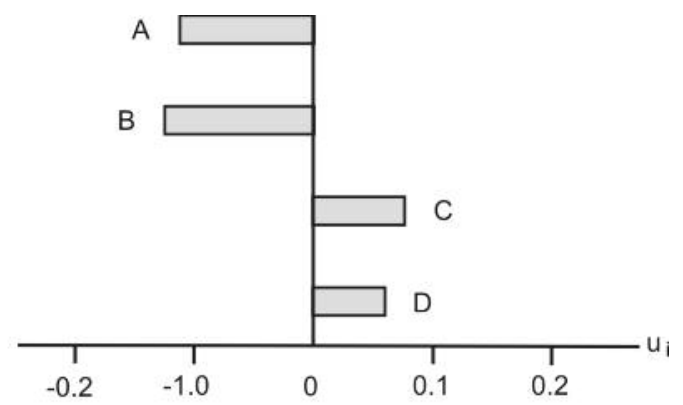

b

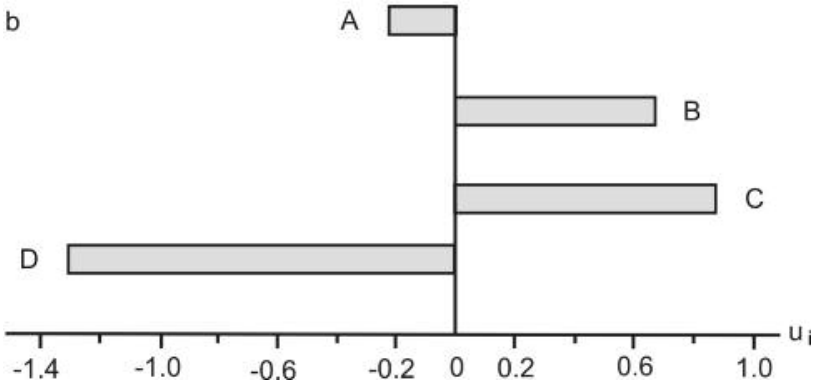

Fig. 3. Mean weight of seeds (a) and mean longevity index (b) expressed in the values of standardized variable " $u$ ".
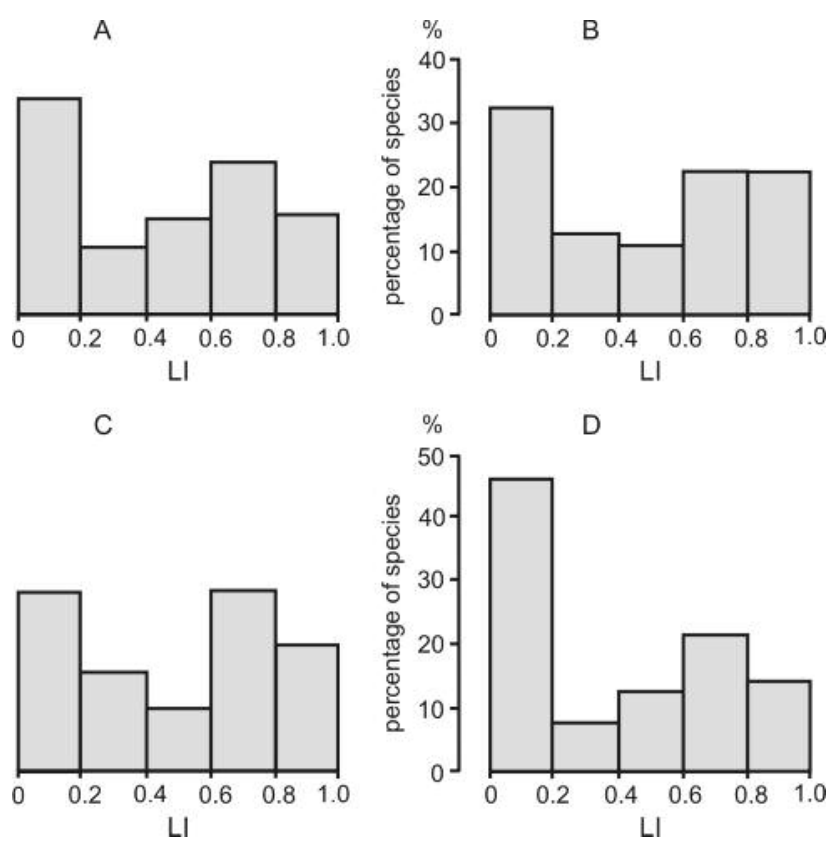

Fig. 4. Distribution of longevity index (LI) in research objects.

\section{DISCUSSION}

A number of publications regarding the discussed subject largely reflect the condition of well-preserved natural forest complexes in Europe and, on a smaller scale, in the North America. Białowieża Primeval Forest, which has been uninterruptedly covered by deciduous forest for thousands of years, is for this reason the only model of natural temperate deciduous forest (Boussuyt and Hermy 2001; Fenner and Thompson 2005; Boussuyt and Honmay 2008).

In view of that, the fact that the seed banks of natural temperate deciduous forests are among the poorest studied types of plant communities should not be surprising (Thompson et al. 1997). However, there are a high number of publications concerning other communities found in all geographical zones (e.g. Grime 1989; Vyvey 1989a-b; Thompson et al. 1997; Chang et al. 2001; Fenner and Thompson 2005).

\section{Seed bank density}

A number of papers have focused on the role of seed banks in different plant dynamics processes, such as primary succession (Tsuyuzaki 1991; Grandin and Rydin 1998; Grandin 2001), secondary succession (Donelan and Thompson 1980; Conn et al. 1984; Symonides 1986; Milberg 1992, 1995; Buckley et al. 1997; Falińska 1999; Hyatt and Casper 2000; Bossuyt and Hermy 2004; Wagner et al. 2006), decline (Panufnik-Mędrzycka and KwiatkowskaFalińska 2001), or regeneration (Jankowska-Błaszczuk 2002). Our study falls within this research mainstream. The analysed communities undergo spontaneous and anthropogenic transformation from sunny Potentillo albae-Quercetum to shady Tilio-Carpinetum, and changes in seed banks are associated with changes in the ground vegetation. The decline of the extensive thermophilous oak wood patch where plots A and D were located has been well documented (Kwiatkowska 1986, 1993, 1994a, b, 1996; Kwiatkowska and Wyszomirski 1988, 1990; Kwiatkowska and Solińska-Górnicka 1993; Kwiatkowska-Falińska 2006). 


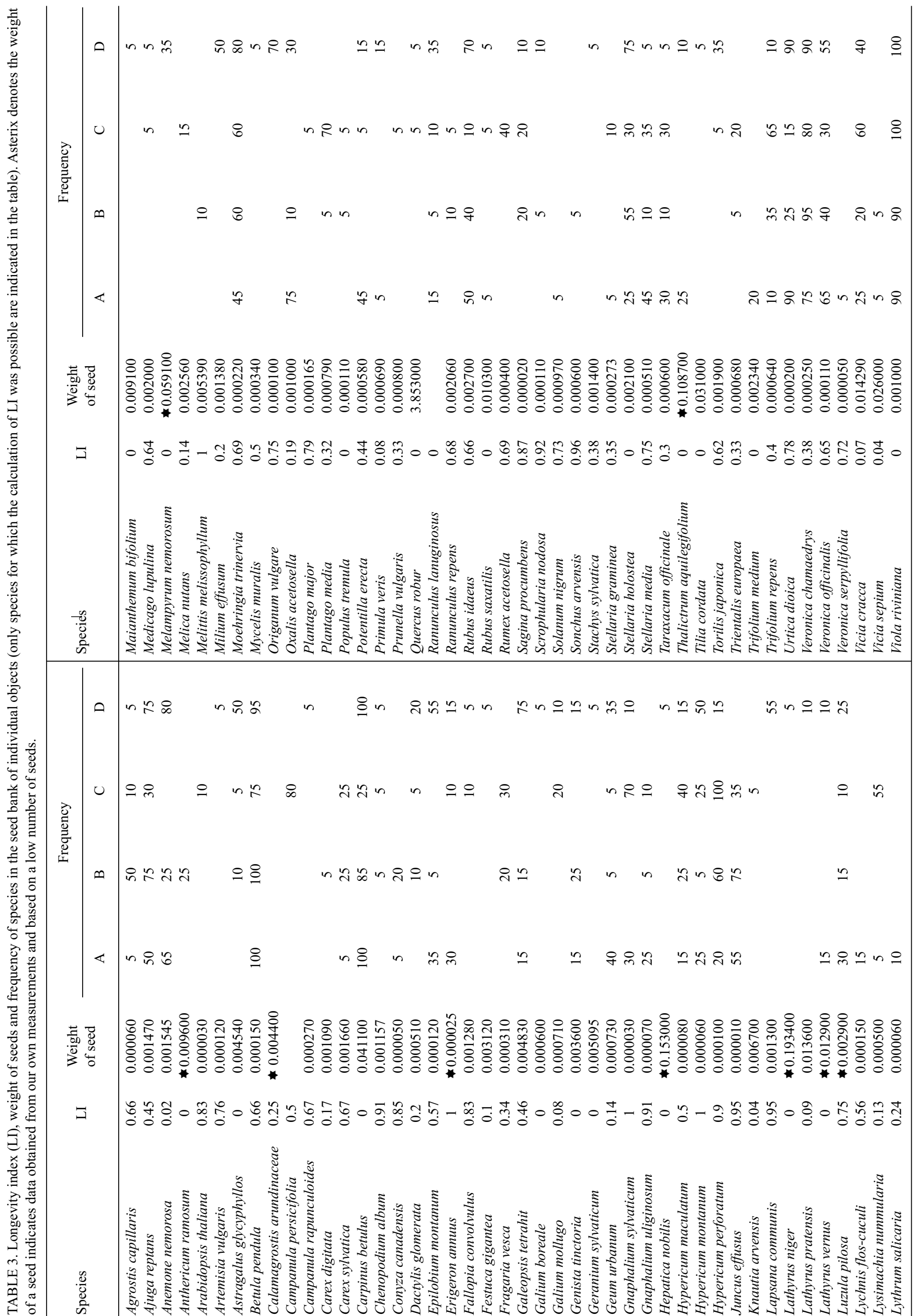


The density of the seed banks of deciduous forests is affected by forest naturalness, forest size, woodstand age, history of patch use and soil type (Bossuyt and Hermy 2001; Bossuyt et al. 2002; Jankowska-Blaszczuk and Grubb 2006). It has been demonstrated that diaspore density in the seed banks of deciduous forest is several times lower than that of open ecosystems. In natural and ancient forest density ranges from about a thousand to a few thousand diaspores per $\mathrm{m}^{2}$ (Marquis 1975; Petrov and Palkina 1983; Pirożnikow 1983; Petrov 1987; Staaf et al. 1987; Pickett and McDonnell 1989; Matlack and Good 1990; Mladenoff 1990; Jankowska-Błaszczuk et al. 1998; Leckie et al. 2000). Data obtained in this study (seedling emergence method conducted for two vegetation seasons) fall within the same range (plot: $\mathrm{C}$ - approx. 1500, D - approx. 2000 seeds per $\mathrm{m}^{2}$ ). A significantly lower seed bank density was found for plots with hornbeam present in the woodstand (plot: A - approx. 450, B - approx. 1000 seeds per $\mathrm{m}^{2}$ ). The strongest negative effect of hornbeam on seed bank density was found in plot $\mathrm{A}$, where hornbeam was present in the woodstand and brushwood. In plot B (after oak logging) the secondary hornbeam woodstand was formed within approx. 80 years, and has already passed the stage of intensive thinning in brushwood layer. It had a lower density than in plot A. The two times higher seed bank density in plot $\mathrm{B}$ compared to plot $\mathrm{A}$, depending mainly on the high proportion of diaspores of heliophilous species, is a repercussion of logging (Table 2).

\section{Diversity and similarity of seed banks and vegetation}

The seed banks of natural undisturbed forests in Białowieża Primeval Forest were characterised by an exceptionally high species diversity and close floristical similarity between the ground vegetation and seed bank (JankowskaBłaszczuk et al. 1998). Diversity in an undisturbed thermophilous oak wood patch (plot D) after the first vegetation season was estimated at 51 species. It increased to 69 species in the second year of observation, when seedlings of 18 species previously absent in the vegetation emerged. This caused a decrease in the similarity index from approx. $70 \%$ (reported by Jankowska-Błaszczuk et al. 1998) to approx. 50\%. This fact is highly significant for methodological aspects and implies that seedling emergence should be observed for longer than one vegetation season. As demonstrated in our study, a number of species germinate in a greenhouse not earlier than in the second year of observation, which is probably associated with the process of "risk spreading germination" (Grubb 1988).

The soil seed bank and ground vegetation of thermophilous oak forest contains a high number of species of high and moderate light demand, which usually form a long-term persistent seed bank (Jankowska-Błaszczuk et al. 1998; Panufnik-Mędrzycka and Kwiatkowska-Falińska 2001). Hornbeam, over its 30-year invasion period, filled in natural gaps between oak canopies in plot A and formed luxuriant brushwood. In this patch overshading of the forest floor resulted in a gradual deletion of species from the characteristic combination in thermophilous oak woods. Heliophilous species were deleted first (Kwiatkowska et al. 1997), and except for three species from genus Hypericum, their diaspores did not survive in the soil for as long a time. Despite low similarity between the vegetation in plots $\mathrm{A}$ and $B(S=37.7 \%)$, seed banks of plots with hornbeam woodstand (formed after logging and spontaneous invasion) demonstrate close similarity (S coefficient approx. $60 \%$ ). Heliophilous species have the highest share in the seed bank of these plots, but they are not present in the vegetation of undisturbed thermophilous oak woods. This group contains, for example, numerous anemochoric species not found in the ground vegetation layer. Similar divergence between the share of species in the ground vegetation and seed bank concerns the diaspores of species from taxa Epilobium, Hypericum, Juncus and Rubus, whose high number is found in almost all types of forest communities growing in the temperate zone (Olano et al. 2002; Godefroid et al. 2006). The ecological literature defines them as "canopy-gap-demanded species" and they are present in all plots, with particular abundance in the seed banks of communities with a history of clear logging. This process also resulted in the closest floristical similarity, between the seed bank of plots B and C ( $>60 \%)$.

All the studied communities were present in the same habitat where undisturbed thermophilous oak woods (plot D). The diversity and similarity of seed banks and vegetation was affected by two factors: hornbeam pressure and logging. Whether the woodstand with hornbeam was formed by invasion into the habitat of thermophilous oak wood, or the hornbeam cohort invaded the clearing, the long-term pressure of hornbeam on the plant cover caused a decrease in the diversity and floristical similarity of seed bank and ground vegetation. Importantly, after such a long time the diaspores of species typical for thermophilous oak wood are not preserved in the seed bank, and this type of disturbance in the natural woodstand disables the restoration of the heliophilous vegetation of Potentillo albaeQuercetum from the pool of diapores present in the soil.

Planting pine on a clear site formed by logging of thermophilous oak wood has opposing consequences. Ploughing retrieves diaspores of thermophilous oak wood species from the deeper layers, so their populations are able to be restored from the pool of diaspores deposited in the soil (Bossuyt and Honnay 2008; Hautala et al. 2008).

\section{Persistence of seed banks}

In our study changes in the seed bank followed changes in the vegetation, which has also been reported by other authors (Bekker et al. 1999) and (Wolters and Bakker 2002). In contrast to the common opinion about the low persistence of seed banks of forest species characterised by low and moderate light demands, their share in the soil seed bank of thermophilous oak wood is relatively constant (Jankowska-Błaszczuk et al. 1998). The presence of shadetolerant species in the seed banks has also been confirmed by Staaf et al. (1987), Buckley et al. (1997), Boussuyt et al. (2002), and Godefroid et al. (2006).

Findings by Panufnik-Mędrzycka and Kwiatkowska-Falińska (2001) indicate that some heliophilous forest species (e.g. Betonica officinalis, Gnaphalium sylvaticum, Potentilla erecta) preserve their germinating potential for over 10 years. A large group of species of high and moderate light demand forms long-term persistent banks according to a classification by Thompson et al. (1997), with diaspore longevity of over five years.

Jankowska-Błaszczuk and Grubb (2006) emphasized that in the initial period of studies on seed banks, the strategy in which persistent seed banks are formed was only attributed 
to species of high light demand. Contrary to the common opinion about the low persistence of seeds of low light demand species (typical for the vegetation of deciduous forests), an increasing amount of data proves their significantly higher share in seed banks (Jankowska-Błaszczuk et al. 1998; Bossuyt et al. 2002). Species characteristic of thermophilous oak forest are preserved even in the seed banks where above-ground vegetation has been exposed to shade for many years.

The evaluation of seed bank persistence based on a mean value and distribution of LI seems to be more promising in the future than at this moment. Firstly, the list of species to which the authors classified individual species to the 1st, 2nd or 3rd type of seed bank is incomplete. Secondly, the number of records for a species is highly variable, which affects the reliability of calculated LI. However, data obtained in this study allow for the conclusion that the correlation between the duration and intensity of shading of the forest floor and the share of species forming long-term persistent seed banks in disturbed patches of thermophilous oak wood is highly probable.

\section{ACKNOWLEDGEMENTS}

The study was partly subsidized from the science fund for 2008-2011 under the framework of research project No. N N 304 025534. Heartfelt thanks to Ms Halina Kościelecka and Ms Alicja Wiktoruk of the Białowieża Geobotanical Station of Warsaw University for their help in the preparation of the typescript for publishing.

\section{LITERATURE CITED}

BEKKER R.M., BAKKER J.P, GRANDIN U., KALAMEES R., MILBERG P., POSCHOLD P., THOMPSON K., WILLEMS J.H. 1998. Seed size, shape and vertical distribution in the soil: indicatores of seed longevity. Functional Ecol. 12: 834-842.

BEKKER R.M., LAMMERTS E.J., SCHUTTER A., GROOTJANS A.P. 1999. Vegetation development in dune slacks: the role of persistent seed banks. J. Veg. Sci. 10: 745-754.

BOSSUYT B., HERMY M. 2001. Influence of land use history on seed banks in European temperate forest ecosystems: a review. Ecography 24.2: 225-238.

BOSSUYT B., HERMY M. 2004. Seed bank assembly follows vegetation succession in dune slacks. J. Veg. Sci. 15: 449-456.

BOSSUYT B., HEYN M., HERMY M. 2002. Seed bank and vegetation composition of forest stands of varying age in central Belgium: consequences for regeneration of ancient forest vegetation. Plant Ecol. 162: 33-48.

BOSSUYT B., HONNAY O. 2008. Can be the seed bank be used for ecological restoration? An overview of seed bank characteristics in European communities. J. Veget. Sci. 19: 875-884.

BUCKLEY G.P., HOWELL R., ANDERSON M.A. 1997. Vegetation succession following ride edge management in lowland plantations and woods. 2. The seed bank resource. Biol. Conserv. 82: 305-316.

CHANG E.R., JEFFERIES R.L., CARLETON T.J. 2001. Relationship between vegetation and soil seed banks in an arctic coastal marsh. J. Ecol. 89: 367-384.

CONN J.S., COCHRANGE C.L., DELAPP J.A. 1984. Soil seed bank changes after forest clearing and agricultural use in Alaska. Weed Sci. 32: 343-347.

DÖLLE M., SCHMIDT W. 2009. The relationship between soil seed bank, above-ground vegetation and disturbance intensity on old-field successional permanent plots. Appl. Veget. Sci. 12.4: 415-428.

DONELAN M., THOMPSON K. 1980. Distribution of buried viable seeds along a successional series. Biol. Conserv. 17: 297-311.

FALIŃSKA K. 1999. Seed bank dynamics in abandoned meadows during a 20-year period in the Białowieża National Park. J. Ecol. 87: 461-475.

FALIŃSKI J.B. 1986. Vegetation dynamics in temperate lowland primeval forests. Ecological studies in Białowieża Forest. Dr W. Junk Publishers ed Dordrecht, Boston, Lancaster.

FENNER M., THOMPSON K. 2005. The Ecology of Seeds. Cambridge University Press, Cambridge.

GODEFROID S., PHARTYAL S.S., KOEDAM N. 2006. Depth distribution and composition of seed banks under different tree layers in a managed temperate forest ecosystem. Acta Oecol. 29: $283-292$.

GRANDIN U. 2001. Short-term and long-term variation in seed bank/vegetation relations along an environmental and successional gradient. Ecography 24: 731-741.

GRANDIN U., RYDIN H. 1998. Attributes of the seed bank after a century of primary succession on islands in Lake Hjalmaren, Sweden. J. Ecol. 86: 293-303.

GRIME J.P. 1989. Seed Banks in Ecological Perspective. In: V.T. Parker, M.A. Leck, R.L. Simpson (eds), The Ecology of Seed Banks. Dr W. Junk, Wageningen p. xv-xxii.

GRUBB P.J. 1988. The uncoupling of disturbance and recruitment, two kinds of seed bank, and persistence of plant populations at the regional and local scales. Ann. Zool. Fennici 25: 23-36.

HARPER J.L. 1977. Population biology of plant. Academic Press, London.

HAUTALA H., TOLVANEN A., NUORTILA C. 2008. Recovery of pristine boreal forest floor community after selective removal of understorey, ground and humus layers. Plant Ecol. 194.2: 273-282.

HOPFENSPERGER K.N. 2007. A review of similarity between seed bank and standing vegetation across ecosystems. Oikos 116: 1438-1448.

HYATT L.A., CASPER B.B. 2000. Seed bank formation during early secondary succession in a temperate deciduous forest. J. Ecol. 88: 516-527.

JANKOWSKA-BŁASZCZUK M. 2002. Variability of soil seeds banks of the natural deciduous forest. Ecol. Quest. 2, 209-221.

JANKOWSKA-BLASZCZUK M., DAWS M.I. 2007. Impact of red: far red ratios on germination of temperate forest herbs in relation to shade tolerance, seed mass and persistence in the soil. Funct. Ecol. 21: 1055-1062.

JANKOWSKA-BŁASZCZUK M., GRUBB P.J. 1997. Soil seed banks in primary and secondary deciduous forest in Białowieża, Poland. Seed Sci. Res. 7: 281-292.

JANKOWSKA-BLASZCZUK M., GRUBB P.J. 2006. Changing perspectives on the role of the soil seed bank in northern temperate deciduous forests and in tropical lowland rain forests: parallels and contrasts. Perspect. Plant Ecol. Evol. System 8: 3-21.

JANKOWSKA-BŁASZCZUK M., KWIATKOWSKA A.J., PANUFNIK D., TANNER E. 1998. The size and diversity of the soil seed banks and the light requirements of the species in sunny and shady natural communities of the Białowieża Primeval Forest. Plant Ecol. 136: 105-118.

KWIATKOWSKA A.J. 1986. Reconstruction of the old range and the present-day boundary of a Potentillo albae-Quercetum (Libb.) 1933 phytocoenosis in the Białowieża Primaeval Forest landscape. Ekol. Pol. 34.1: 31-45.

KWIATKOWSKA A.J. 1993. Phytoindication analysis of temporal and spatial variation of light, trophic and moisture conditions in oak forest habitat. Fragm. Flor. Geobot. 38: 173-182.

KWIATKOWSKA A.J. 1994a. Effect of species diversity, frequency and spatial distribution of the species-area relationship in oak forest stand. Ann. Bot. Fen. 31: 169-178. 
KWIATKOWSKA A.J. 1994b. Changes in the species richness, spatial pattern and species frequency associated with the decline of oak forest. Vegetatio 112: 171-180.

KWIATKOWSKA A.J. 1996. Zmiana presji roślinożerców jako przyczyna regresji świetlistych w Puszczy Białowieskiej. Wiad. Ekol. 42: 137-162. (in Polish)

KWIATKOWSKA-FALIŃSKA A.J. 2006. The pressure of dominant herbivores and the process of secondary succession of Potentillo albae-Quercetum in Białowieża Primeval Forest. Coll. Phytosoc. 29: 185-212

KWIATKOWSKA A.J., SOLIŃSKA-GÓRNICKA B. 1993. Changes in typological and spatial boundaries between neighbouring communities of Potentillo albae-Quercetum and TilioCarpinetum. Acta Soc. Bot. Pol. 62: 59-66.

KWIATKOWSKA A.J., SPALIK K., MICHALAK E., PALIŃSKA A., PANUFNIK D. 1997. Influence of the size and density of Carpinus betulus on the spatial distribution and rate of deletion of forest-floor species in thermophilous oak forest. Plant Ecol. 129: 1-10.

KWIATKOWSKA A.J., WYSZOMIRSKI T. 1988. Decline of Potentillo albae-Quercetum phytocoenoses associated with the invasion of Carpinus betulus. Vegetatio 75: 49-55.

KWIATKOWSKA A.J., WYSZOMIRSKI T. 1990. Species deletion in Potentillo albae-Quercetum phytocoenoses reserved by the removal of Carpinus betulus. Vegetatio 87: 115-126.

LECK M.A., PARKER V.T., SIMPSON R.I. 1989. Ecology of soil seed banks. Academic Press, San Diego.

LECKIE S., VELLEND M., BELL G., WATERWAY M.J., LECHOWICZ M.J. 2000. The seed bank in an old-growth, temperate deciduous forest. Can. J. Bot. 78: 181-192.

MARQUIS D.A. 1975. Seed storage and germination under northern hardwood forests. Can. J. For. Res. 5: 478-484.

MATLACK G.R., GOOD R.E. 1990. Spatial heterogenoity in the soil seed bank of a mature Coastal Plain forest. Bull. Torr. Bot. Club. 117: 143-152.

MILBERG P. 1992. Seed bank in 35-year-old experiment with different treatments of a seminatural grassland. Acta Oecol. 13: 743-752.

MILBERG P. 1995. Soil seed bank after eighteen years of succession from grassland to forest. Oikos 72: 3-13.

MLADENOFF D.J. 1990. The relationship of the soil seed bank and understory vegetation in old-growth northern hardwoodhemlock treefall gaps. Can. J. Bot. 68: 2714-2721.

OLANO J.M., CABALLERO I., LASKURAIN N.A., LOIDI J., ESCUDERO A. 2002. Seed bank spatial pattern in a temperate secondary forest. J. Veget. Sci. 13: 775-784.

PANUFNIK-MĘDRZYCKA D., KWIATKOWSKA-FALIŃSKA A.J. 2001. The realised and potential soil seed bank in the Potentillo albae-Quercetum community in the Białowieża Primeval Forest. Acta Soc. Bot. Pol. 70: 133-143.

PETROV V.V. 1987. New data on the seed bank i $n$ the soil under broad-leaved deciduous forests. Vestnik Moskovskovo Universiteta, Biologija 42: 55-59.
PETROV V.V., PALKINA T.L. 1983. The content of the dormant viable seeds in the soil of a broad-leaved forest and a spruce plantation. Vestnik Moskovskovo Universiteta, Biologija 38: 31-35.

PICKETT S.T.A., MCDONNELL M.J. 1989. Seed bank dynamics in temperate deciduous forest. In: M.A. Leck, V.T. Parker, R.L. Simpson (eds), Ecology of Soil Seed Banks. Academic Press, San Diego, p. 123-147.

PIROŻNIKOW E. 1983. Seed bank in the Soil of Stabilized Ecosystem of a Deciduous Forest (Tilio-Carpinetum) in the Białowieża National Park. Ekol. Pol. 31: 145-172.

SOKAL R.R., ROLF F.J. 1981. Biometry. W.H. Freeman and Company, New York.

SØRENSEN T. 1948. A method of establishing groups of equal amplitude in plant society based on similarity of species content. K. Danske Vidensk, Selesk 5: 1-34.

STAAF H., JONSSON M., OLSÉN L.G. 1987. Buried germinative seeds in mature beech forests with different herbaceous vegetation and soil types. Ecography 10.4: 268-277.

SYMONIDES E. 1986. Seed bank in old field successional ecosystems. Ekol. Pol. 34: 3-29.

TER HEERDT G.J.N., VERWEIJ G.L., BEKKER R.M., BAKKER J.P. 1996. An improved method for soil seed bank analysis: Seedling removal after removing the soil by sieving. Funct. Ecol. 10: 144-151

THOMPSON K. 1992. The Functional Ecology of Seed Banks. In: M. Fenner (ed.), The Ecology of Regeneration in Plant Communities. CAB International Wallingford, Oxford, p. 231-258.

THOMPSON K., BEKKER R.M., BAKKER J.P. 1997. The Soil Seed Banks of Northwest Europe: Methodology, Density and Longevity. Cambridge University Press, Cambridge, UK.

THOMPSON K., GRIME J.P. 1979. Seasonal variation in the seed banks of herbaceous species in ten contrasting habitats. J. Ecol. 67: 893-921.

TSUYUZAKI S. 1991. Survival characteristics of buried seeds 10 years after the eruption of the Usu volcano in Northern Japan. Can. J. Bot. 69: 2251-2256.

VYVEY Q. 1989a. Bibliographical review on buried viable seeds in the soil. Excerpta Bot. Sect. B 26: 311-320.

VYVEY Q. 1989b. Bibliographical review on buried viable seeds in the soil. Excerpta Bot. Sect. B 27: 1-52.

WAGNER M., HEINRICH W., JETSCHKEA G. 2006. Seed bank assembly in an unmanaged ruderal grassland recovering from long-term exposure to industrial emissions. Acta Oecol. 30: 342-352.

WOLTERS M., BAKKER J.P. 2002. Soil seed bank and driftline composition along a successional gradient on a temperate salt marsh. Appl. Veget. Sci. 5: 55-62.

WÓDKIEWICZ M., KWIATKOWSKA-FALIŃSKA A.J. 2010a. Similarity between seed bank and herb layer in a natural deciduous temperate lowland forest. Acta Soc. Bot. Pol. 79.2: 157-166.

WÓDKIEWICZ M., KWIATKOWSKA-FALIŃSKA A.J. $2010 \mathrm{~b}$. Small scale spatial pattern of a soil seed bank in an old-growth deciduous forest. Pol. J. Ecol. 58.3: 487-500. 